\title{
Prediksi Service Quality, Destination Image Terhadap Destination Loyalty Pengunjung Pura Luhur Uluwatu
}

\author{
Stephanie dan Hetty Karunia Tunjungsari \\ Program Studi Manajemen Fakultas Ekonomi Universitas Tarumanagara, Jakarta \\ Email: stephanie.anastasia@yahoo.com
}

\begin{abstract}
The purpose of research was to determine the effect of service quality, destination image on destination loyalty. In this study, 108 respondents of local tourists were chosen to visit the Uluwatu Bali Temple. This study uses a descriptive method, namely Cross-Sectional design that studies the dynamics of the correlation between risk factors in one population. The sample selection method used in this study is a nonprobability sampling method. The results of this study indicate that the destination image can be a mediator between service quality and destination image.
\end{abstract}

Keywords: service quality, destination image, destination loyalty, tourism perspective.

Abstrak: Tujuan dari penelitian ini adalah untuk menguji apakah destination image memiliki peran dalam mempengaruhi hubungan antara service quality dan destination loyalty. Dalam penelitian ini dipilih sebanyak 108 responden wisatawan local yang mengunjungi Pura Luhur Uluwatu Bali. Penelitian ini menggunakan metode deskriptif, yakni desain Cross-Sectional yang mempelajari dinamika korelasi antara faktor-faktor resiko di satu populasi. Metode pemilihan sampel yang digunakan pada penelitian ini adalah metode tidak acak (purposive sampling). Hasil penelitian ini menunjukan bahwa destination image dapat menjadi mediator antara service quality dan destination image.

Kata Kunci: kualitas layanan, citra destinasi, loyalitas destinasi, perspektif turis.

\section{LATAR BELAKANG}

Pariwisata merupakan salah satu sektor yang dapat diandalkan dalam perekonomian nasional. Kita juga mengetahui bahwa pariwisawa merupakan salah satu sektor yang dapat meningkatkan pertumbuhan ekonomi negara dengan cepat seperti hal nya dalam menyediakan lapangan pekerjaan, dan meliputi industri rumahan seperti kerajinan tangan, penginapan, pemandu wisata, dan transportasi. Seiring dengan berjalannya waktu, persaingan pada bidang jasa pun semakin ketat, sama hal nya dalam pariwisata.

Berdasarkan pemaparan diatas, penulis akan membahas salah satu objek wisata yang berada di Indonesia, yaitu Bali. Ada beberapa factor yang mempengaruhi minat wisatawan untuk mengunjungi objek wisata pura uluwatu bali, salah satunya yaitu kualitas layanan atau service quality. Dan berdasarkan penelitian yang telah dilakukan sebelumnya menunjukan bahwa hubungan antara kualitas layanan, citra destinasi dan loyalitas belum sepenuhnya diteliti khususnya di bidang industry pariwisata (Gupta and Chen, 1995; Voss et al., 2003; Vinh and Long, 2013; Yang et al., 2014). Selain itu penelitian sebelumnya yang diteliti oleh Myagmarsuren and Chen, 2011; Upadhyaya, 2012; Farias et al., 2013, juga mengatakan bahwa hubungan antara dimensi kualitas layanan dan loyalitas tujuan dan 
bagaimana dimensi ini dapat mempengaruhi penggunaan citra destinasi sebagai mediator belum sepenuhnya diteliti, sehingga menarik bagi kita untuk membahas hal tersebut.

\section{KAJIAN TEORI}

Penelitian ini mengacu pada theory of planned behavior (TPB) yang merupakan perluasan dari Theory of reasoned action (TRA). Teori TRA ini menjelaskan bahwa niat seseorang terhadap perilaku dibentuk oleh dua faktor yang mempengaruhi. Kedua factor tersebut yaitu sikap terhadap perilaku (attitude toward behavior) dan dan norma subjektif (subjective norm). Pada teori TPB ditambahkan satu factor lagi yaitu perceived behavioral control menurut Ajzen (1991). Biasanya theory of planned behavior (TPB) digunakan untuk melakukan penelitian mengenai perilaku.

\section{Pengaruh service quality terhadap destination loyalty}

Dalam penelitian yang telah dilakukan sebelumnya oleh Yoon and Uysal (2005) menjelaskan bahwa bahwa jika wisatawan mendapatkan pelayanan yang baik dari suatu tujuan, maka mereka akan setia untuk mengunjungi kembali tempat wisata tersebut.

\section{Pengaruh destination image terhadap destination loyalty}

Bologlu \& McClearly (1999) menuliskan bahwa citra destinasi mempengaruhi wisatawan dalam memilih tujuan wisata, persepsi mereka, dan juga niat dimasa depan.

\section{Kerangka pemikiran :}

Seperti yang kita ketahui service quality penting bagi suatu tempat wisata. Destination image yang baik akan mempengaruhi destination loyalty secara positif. Service quality juga termasuk media yang digunakan untuk membangun destination image suatu tempat wisata.

Hipotesis dalam penelitian ini adalah sebagai berikut :

$\mathrm{H}_{1}$ : Service Quality merupakan predictor yang positif dari Destination Image

$\mathrm{H}_{2}$ : Destination Image merupakan predictor yang positif dari Destination Loyalty

$\mathrm{H}_{3}$ : Service Quality merupakan predictor yang positif dari Destination Image

$\mathrm{H}_{4}$ : Destination Image merupakan mediator antara Service Quality dan Destination Loyalty

\section{METODOLOGI}

Penelitian ini menggunakan metode deskriptif, yakni desain Cross-Sectional Selain itu, saya menggunakan penelitian deskriptif adalah karena tidak ada variable yang dimanipulasi. Penelitian ini menggunakan skala Likert (interval). Skala likert yang digunakan untuk mengukur kuesioner ini menggunakan skala 1 sampai 6. Penelitian ini merupakan cross-sectional study dimana penelitian dilakukan hanya dalam satu periode penelitian terhadap beberapa sampel dalam populasi (Malhotra, 2004). Metode pemilihan sampel yang digunakan pada penelitian ini adalah metode tidak acak (non-probability sampling). Sedangkan teknik yang digunakan dalam penelitian ini adalah teknik tidak acak (purposive sampling). Dalam penelitian ini dipilih sebanyak 108 responden. 


\section{Definisi Operasional Penelitian Variabel Service Quality}

Service quality merupakan evaluasi yang terfokus mencerminkan persepsi pelanggan tentang dimensi layanan tertentu yaitu keandalan, daya tanggap, jaminan, empati, dan bukti fisik.

\section{Definisi Operasional Penelitian Variabel Destination Image}

Destination image atau citra destinasi merupakan persepsi wisatawan tentang suatu destinasi

Definisi Operasional Penelitian Variabel Destination Loyalty

Destination loyalty adalah persepsi wisatawan tentang suatu destinasi sebagai tempat yang direkomendasikan

\section{Hasil Analisis Data}

\section{Uji Validitas}

\section{a. Service Quality}

Setiap pernyataan mengenai Service Quality sudah disebar kepada 108 responden dan hasil uji validitas yang diperoleh menunjukan bahwa semua pernyataan memiliki corrected item-total correlation $>0,3$. Dengan demikian semua pernyataan dinyatakan valid.

Tabel 1. Uji Validitas Service Quality

\begin{tabular}{|c|c|c|}
\hline Pernyataan & $\begin{array}{c}\text { Corrected item- } \\
\text { total correlation }\end{array}$ & Keterangan \\
\hline SQ 1 & 0,738 & Valid \\
\hline SQ 2 & 0,674 & Valid \\
\hline SQ 3 & 0,727 & Valid \\
\hline SQ 4 & 0,704 & Valid \\
\hline SQ 5 & 0,784 & Valid \\
\hline SQ 6 & 0,749 & Valid \\
\hline SQ 7 & 0,657 & Valid \\
\hline SQ 8 & 0,715 & Valid \\
\hline SQ 9 & 0,657 & Valid \\
\hline SQ 10 & 0,682 & Valid \\
\hline SQ 11 & 0,698 & Valid \\
\hline SQ 12 & 0,712 & Valid \\
\hline SQ 13 & 0,708 & Valid \\
\hline SQ 14 & 0,652 & Valid \\
\hline SQ 15 & 0,681 & Valid \\
\hline
\end{tabular}

Berdasarkan table, setiap butir pernyataan mengenai service quality memiliki nilai koreksi $>0,3$, artinya nilai korelasi total dari item terkoreksi memiliki makna bahwa kelima item dinyatakan valid.

\section{b. Destination Image}


Setiap pernyataan mengenai Destination Image sudah disebar kepada 108 responden dan hasil uji validitas yang diperoleh menunjukan bahwa semua pernyataan memiliki corrected item-total correlation $>0,3$. Dengan demikian semua pernyataan dinyatakan valid.

Tabel 2. Uji Validitas Destination Image

\begin{tabular}{|c|c|c|}
\hline Pernyataan & $\begin{array}{c}\text { Corrected item-total } \\
\text { correlation }\end{array}$ & Keterangan \\
\hline DI 1 & 0,750 & Valid \\
\hline DI 2 & 0,639 & Valid \\
\hline DI 3 & 0,723 & Valid \\
\hline DI 4 & 0,680 & Valid \\
\hline DI 5 & 0,709 & Valid \\
\hline
\end{tabular}

\section{c. Destination Loyalty}

Setiap pernyataan mengenai Destination Loyalty sudah disebar kepada 108 responden dan hasil uji validitas yang diperoleh menunjukan bahwa semua pernyataan memiliki corrected item-total correlation $>0,3$. Dengan demikian semua pernyataan dinyatakan valid

Tabel 3. Uji Validitas Destination Loyalty

\begin{tabular}{|c|c|c|}
\hline Pernyataan & $\begin{array}{c}\text { Corrected item- } \\
\text { total correlation }\end{array}$ & Keterangan \\
\hline DL 1 & 0,457 & Valid \\
\hline DL 2 & 0,761 & Valid \\
\hline DL 3 & 0,793 & Valid \\
\hline DL 4 & 0,655 & Valid \\
\hline
\end{tabular}

\section{Uji Reliabilitas}

Menurut Sugiyono (2013) reliabilitas adalah instrument yang bila di gunakan beberapa kali untuk mengukur objek yang sama, akan menghasilkan data yang sama. Uji reliabilitas dilakukan dengan membandingkan nilai koefisien Cronbach's Alpha $(\alpha)>0,7$ maka dapat dikatakan reliabel. Berdasarkan hasil uji terhadap 108 responden maka diperoleh hasil yang reliabel karena memiliki nilai Cronbach's Alpha $>0,7$.

\section{Uji asumsi klasik}

a. Uji Normalitas

Dan berdasarkan data yang diperoleh, dari tiga uji model menggambarkan bahwa pola distribusi normal dan menyebar di sekitar garis diagonal sehingga memenuhi syarat.

\section{b. Uji Multikolinieritas}

Berdasarkan hasil uji, maka diperoleh data bahwa Jika tidak terjadi korelasi di antara variabel independen maka itu merupakan regresi yang baik dan tidak terjadi multikolinearitas.

\section{c. Uji Heteroskedastisitas}


Dari hasil uji heterokedastisitas, maka terlihat jelas bahwa titik-titik menyebar secara acak baik diatas maupun dibawah angka nol (0) pada sumbu Y. Dengan demikian, tidak terjadi heterokedastisitas pada ketiga model regresi

\section{Analisis Regresi Berganda}

. Model analisi regresi berganda (1) digunakan untuk mengetahui pengaruh service quality terhadap destination image. Model analisis regresi berganda (2) digunakan untuk mengetahui pengaruh service quality terhadap destination loyalty. Model analisis regresi berganda (3) digunakan untuk mengetahui pengaruh service quality terhadap destination loyalty. Model linear analisis regresi berganda dalam penelitian ini dirumuskan sebagai berikut :

\section{Uji-F}

Uji-F sudah dilakukan terhadap tiga model regresi. Hasil ketiga sig dibawah 0,05 maka dapat disimpulkan terdapat pengaruh yang signifikan variable independen terhadap variable dependen secara simultan pada ketiga model regresi.

1. Uji-t

Uji-t dilakukan untuk mengetahui seberapa besar pengaruh satu variable independen terhadap variable dependen scara parsial. Jika nilai signifikansi lebih kecil dari 0,05 maka Ho ditolak. Hasil uji-t menunjukan bahwa adanya pengaruh yang positif.

\section{Uji Pengaruh Mediasi}

Dalam menguji pengaruh mediasi, digunakan uji causal step berdasarkan ketentuan dari Baron dan Keny (1986) dan uji sobel

Gambar 4.7 Analisis Jalur Service Quality ke Destination Loyalty

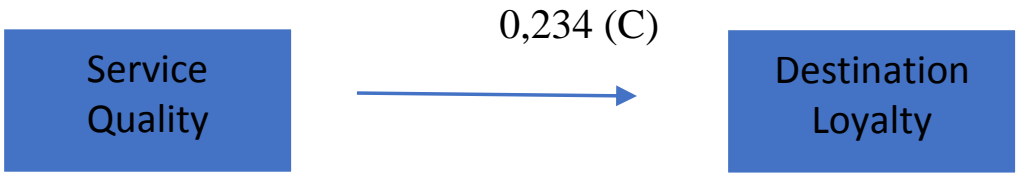

Gambar 4.8 Analisis Jalur Service Quality ke Destination Loyalty melalui Destination Image

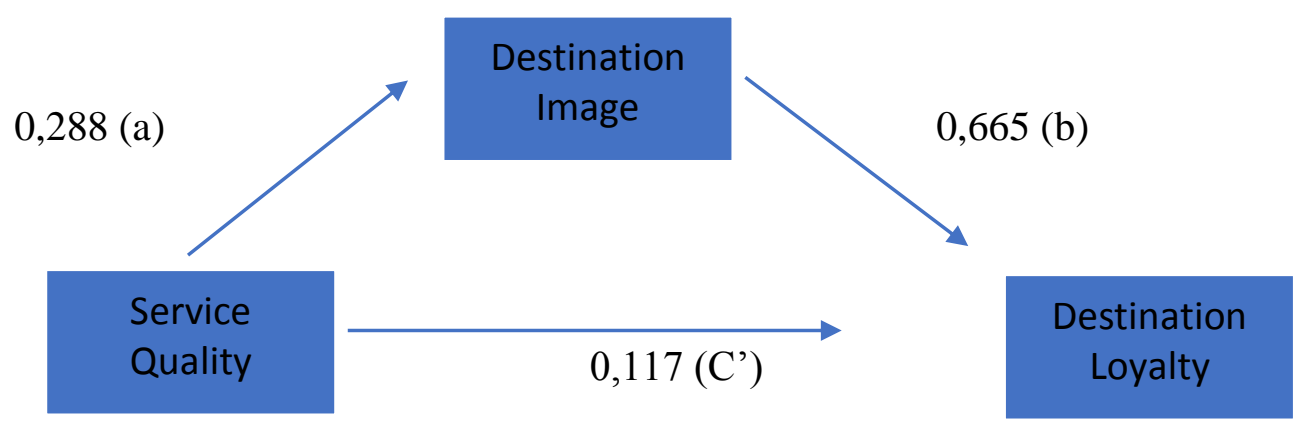


Dengan demikian terjadi partial mediation, karena koefisien c' berkurang namun tetap signifikan ( $c^{\prime} \neq 0$ ). Maka $\mathrm{H}_{4}$ tidak ditolak, destination image merupakan mediator antara service quality dan destination loyalty.

\section{Uji Sobel :}

$\mathrm{Sab}=\sqrt{b 2 S a 2+a 2 S b 2+S a 2 S b 2}$

$\mathrm{Sab}=0,0344$

Untuk menguji signifikansi pengaruh tidak langsung, maka perlu dilakukan penghitungan nilai $t$ dari koefisien dengan rumus sebagai berikut :

$$
\begin{aligned}
& t=\frac{0,288 \times 0,665}{0,0344} \\
& =5,5674>3,699 \\
& =\text { memediasi }
\end{aligned}
$$$$
\boldsymbol{t}=\frac{a b}{S a b}
$$

\section{DISKUSI}

Hasil penelitian ini menunjukan bahwa destination image merupakan mediator antara service quality dan destination loyalty. Dari hasil penelitian tersebut dapat disimpulkan, apabila service quality yang diberikan oleh Pura Luhur Uluwatu adalah positif maka, maka hal itu akan dapat menentukan destination image Pura Luhur Uluwatu dan berpengaruh pula terhadap destination loyalty konsumen untuk mengunjungi Pura Luhur Uluwatu. Hal ini selaras dengan penelitian yang telah dilakukan oleh Yoon dan Uysal (2015) yang mengatakan bahwa organisasi atau negara perlu mengembangkan citra merek wisatawan berdasarkan lima dimensi service quality guna menarik wisatawan untuk mengunjungi kembali tempat wisata tersebut.

\section{PENUTUP}

Dalam penelitian ini, penulis menyadari masih banyak keterbatasan yang ada, seperti mayoritas responden yang didapatkan terpusat pada satu wilayah (Jakarta) sehingga hasil penelitian kurang bisa digeneralisasikan dan spesifik. Bagi peneliti selanjutnya diharapkan untuk mengembangkan penelitian dengan menambah variable lain diluar variable yang telah diteliti oleh penulis dalam penelitian ini agar memperoleh hasil yang lebih variatif dan dapat memperkaya teori yang sudah ada.

\section{DAFTAR PUSTAKA}

Akroush, M. (2008), "Exploring the mediation effect of service quality implementation on the relationship between service quality and performance in the banking industry in Jordan", Global Business and Economics Review (GBER): An International Journal, Vol. 10 No.1, pp. $98-122$.

Aritonang R., Lerbin R. (2007). Riset Pemasaran, Jakarta: Rajawali Press.

Baloglu, S. and McCleary, K.W. (1999), "A model of destination image formation", 
Annals of Tourism Research, Vol.35 No.4, pp.11-15.

Baron, R. and Kenny, D. (1986), "The moderator-mediator variable distinction in social psychological research: conceptual, strategic, and statistical consideration", Journal of Personality and Social Psychology, Vol. 51 No. 6, pp. 1173-1182.

Faullant, R., Matzler, K. and Fuller, J. (2008), "The impact of satisfaction and image on loyalty: the case of Alpine ski resorts", Managing Service Quality, Vol. 18 No. 2, pp. 163-178.

Ghozali,I., 2006, "Analisis Multivariate dengan Program SPSS”, Badan Penerbit Universitas Diponegoro, Semarang.

Gupta, A. and Chen, I. (1995), "Service quality: implications for management development", International Journal of Quality \& Reliability Management, Vol.12 No.7, pp. 28-35.

Kotler, Philip, 1994, Manajemen Pemasaran (Analisis, Perencanaan, Implementasi dan Pengendalian), Jakarta, Erlangga .

Maholtra. (2010) Basic Marketing Research. $4^{\text {th }}$ edition. Boston : Peason Education.

Moon, K., Kim, M., Ko, Y., Connaughton, D. and Lee, J. (2011), “The influence of consumer's event quality perception on destination image", Managing Service Quality, Vol. 21 No. 3, pp. 287-303.

Myagmarsuren, O. and Chen, C. (2011), "Exploring relationships between destination brand equity, satisfaction, and destination loyalty: a case Study of Mongolia", Journal of Tourism, Hospitality and Culinary Arts, Vol. 3 No. 2, pp. 81-94.

Parasuraman, A., Zeithaml, V. A., and Berry, L. L. (1994), "Reassessment of expectations as a comparison standard in measuring service quality: implications for further research", Journal of Marketing, Vol. 58 No. 1, pp. 111-124.

Sugiyono. 2013. Metode Penelitian Bisnis. Bandung: Alfabeta. 